\title{
SEDIMENT TRANSPORT AND SHORELINE RESPONSE TO NEARSHORE PLACEMENT OF DREDGED SEDIMENT IN SOUTHERN LAKE MICHIGAN, USA
}

Brian C. McFall, US Army Engineer Research and Development Center ${ }^{1}$, Brian.C.McFall@usace.army.mil, Honghai Li ${ }^{1}$, David Arnold ${ }^{1}$, Katherine E. Brutsché ${ }^{1}$, David Bucaro², Erin Maloney², US Army Engineer District, Chicago ${ }^{2}$

\begin{abstract}
Shoreline erosion downdrift of littoral barriers, such as harbor breakwaters, is a universal concern. The beneficial use of dredged sediment through placement in the nearshore downdrift of littoral barriers is common place, but key questions about the sediment transport and shoreline response remain challenging. To that end, the shoreline at Ogden Dunes, Indiana, along the southern shores of Lake Michigan is investigated with historical aerial photographs, nearshore placement records, hydrodynamic and bathymetric field data, and numerical models.
\end{abstract}

The shoreline changes at Ogden Dunes have been a concern for the U.S. Army Corps of Engineers, the National Park Service, Indiana Department of Natural Resources, the Town of Ogden Dunes, and other municipal and private entities. Nearly $1.6 \mathrm{Mm}^{3}\left(2 \mathrm{Myd}^{3}\right)$ of dredged sediment from the Port of Indiana, the Burns Small Boat Harbor, and the Northern Indiana Public Service Company (NIPSCO) intake have been beneficially used by placement in the nearshore or directly on the Ogden Dunes beach since 1982. The dredged sediment primarily consists of fine sand suitable for beach nourishment.

The nearshore placement permit allows the sediment to be placed in depths up to $5.5 \mathrm{~m}(18 \mathrm{ft})$. The current nearshore placement technique consists of placing sediment as deep as the nearshore placement permit allows in small discrete mounds to prevent the sediment from obstructing the hanging gates of the scow from closing. Preliminary analysis of the current placement technique is conducted with the Sediment Mobility Tool (McFall et al., 2016) using wave hindcasts from the Wave Information Study (WIS). The placed sediment was estimated to be mobilized by $37-48 \%$ of the hourly significant waves, and migrate onshore by $64 \%$ of the waves when mobilized.

Shoreline analysis of the site has been conducted using historical aerial photographs, historical Lake Michigan water level measurements, and dredged sediment placement records. The net shoreline movement between successive aerial images was studied using the U.S. Geological Survey's Digital Shoreline Analysis System (Thieler et al., 2008), and shoreline change statistics were derived. Significant erosion was observed in the site after the highly erosive conditions of high water levels and several storms in the mid-1980's. The shoreline largely recovered by the 2000's after many years of nearshore placement of dredged sediment (Arnold et al., 2018).

In the summer of $2016,107,000 \mathrm{~m}^{3}\left(140,000 \mathrm{yd}^{3}\right)$ of dredged sediment from the Port of Indiana and the NIPSCO intake was placed in the nearshore (Figure 1). The hydrodynamic conditions were measured with two Acoustic Doppler Current Profilers (ADCP's), one offshore of the placement and one nearshore of the placement. The offshore ADCP was buried during placement operations and the data from the instrument was unusable. The sediment migration of the placed sediment was monitored with three bathymetric surveys, one pre-placement and two post-placement. The nearshore placement was studied through November 2016.

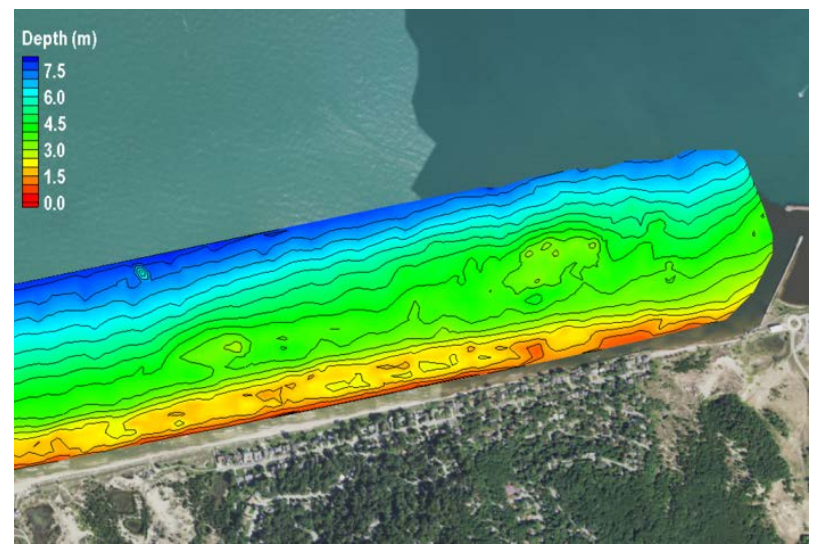

Figure 1 - Bathymetric contours of nearshore placement at Ogden Dunes, IN.

In addition to the nearshore sediment movement predictions from the historically averaged Sediment Mobility Tool, the 2016 nearshore placement was numerically modeled with the Coastal Modeling System (CMS). CMS is a suite of hydrodynamic, wave, and sediment transport models. Coupling CMS-Flow and CMSWave provides a full quantification of waves, currents, and sediment transport for the area (Demirbilek and Rosati, 2011; Lin et al., 2008). The CMS model used wind and wave conditions from an offshore wave buoy and the wave transformation into the nearshore was validated with the nearshore ADCP during the same time frame as the bathymetric surveys. The numerical model provided insight into changes of the local wave-current-sediment interaction at this site.

The wind during the summer was relatively calm at the offshore buoy site with a mean wind speed of $4.6 \mathrm{~m} / \mathrm{s}$ $(15.1 \mathrm{ft} / \mathrm{s})$ and dominant wind direction from the south. The fall was characterized by alternating southerly and northerly winds and the mean wind speed was $7.4 \mathrm{~m} / \mathrm{s}$ $(24.3 \mathrm{ft} / \mathrm{s})$. The significant wave height at the offshore buoy during the summer was $0.4 \mathrm{~m}(1.3 \mathrm{ft})$ and was $1.0 \mathrm{~m}(3.3 \mathrm{ft})$ during the fall.

In the nearshore placement area, the average significant wave height measured by the ADCP was $0.14 \mathrm{~m}(0.5 \mathrm{ft})$ during the summer and $0.6 \mathrm{~m}(2.0 \mathrm{ft})$ during the fall. Significant wave heights greater than $1 \mathrm{~m}(3.3 \mathrm{ft})$ occurred more frequently during the fall period. The average nearshore significant wave height and peak wave period for the entire study period (summer and fall) were $0.4 \mathrm{~m}$ $(1.3 \mathrm{ft})$ and $3.8 \mathrm{~s}$, respectively.

The dominant longshore current and sediment transport in the study area is towards the south-southwest. The 
average calculated current in the surf zone was less than $0.1 \mathrm{~m} / \mathrm{s}(0.3 \mathrm{ft} / \mathrm{s})$ and was less than $0.02 \mathrm{~m} / \mathrm{s}(0.07 \mathrm{ft} / \mathrm{s})$ in the offshore area.

During a storm event on 11 November 2016, the dominant wind blew from north-northeast and the wind speed was greater than $12 \mathrm{~m} / \mathrm{s}(39 \mathrm{ft} / \mathrm{s})$. Corresponding to the wind conditions, wave height was around $2.0 \mathrm{~m}(6.6 \mathrm{ft})$ offshore and propagated from the north-northeast. During this event the modeled nearshore longshore current accelerated towards the south-southwest with a maximum speed as high as $0.7 \mathrm{~m} / \mathrm{s}(2.3 \mathrm{ft} / \mathrm{s})$ in the surf zone. The calculated nearshore significant wave height and direction are shown in Figure 2 during this storm event.

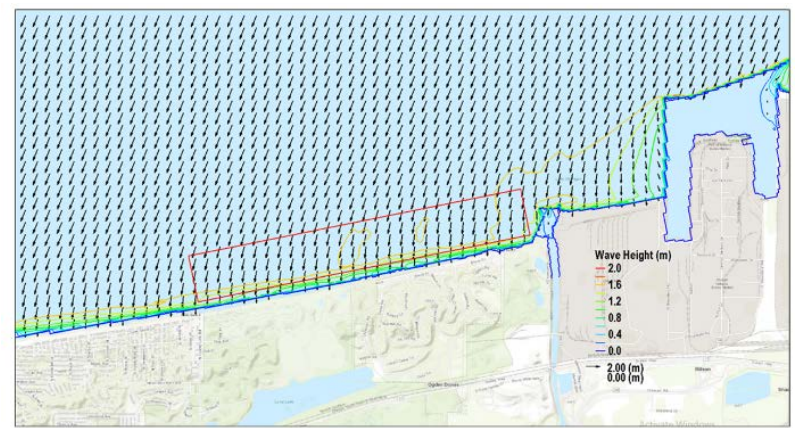

Figure 2 - Calculated significant wave height at direction during the 11 November 2016 storm at 16:00 GMT. The limits of the study area is shown with the red rectangle.

The mean sediment transport pattern in the nearshore corresponded closely with the mean current pattern in a south-southwestward direction along the shoreline. Sediment movement was driven by the mean longshore current and the dominant storm waves from the north during the simulation period. In general, the calculations indicate that coastal sediments were dominantly transported alongshore towards the south-southwest and no apparent sediment movement was identified in the deeper lake area. This matches the results of the Sediment Mobility Tool with longshore sediment transport and accretionary conditions under typical waves.

The field data collection in this study provided an integral component for the evaluation of physical forces driving sediment transport in the study area, and validation of nearshore sediment movement for the two different numerical modeling approaches studied.

The CMS results demonstrate the model's capability to simulate waves, current, sediment transport, and morphology changes in a coastal lake environment. Currents were weak in offshore area but storm-/wavedriven currents were dominant in the surf zone area. The calculated morphology changes show that more sediment movement occurs in the nearshore area driven by the stronger longshore currents. The model validation of the morphology demonstrates the model's capability to calculate bed volumetric changes and sand migration.

Techniques used in this study can be used to investigate the sediment transport and shoreline response to nearshore placement of dredged sediment projects located on the southern shores of the Great Lakes.

\section{REFERENCES}

Arnold, McFall, Brutsché, Maloney, and Bucaro (2018): Nearshore placement techniques in southern Lake Michigan. Technical Report ERDC/CHL-TR-18-3. Vicksburg, MS.

Demirbilek and Rosati (2011): Verification and Validation of the Coastal Modeling System: Report I, Executive Summary. Technical Report ERDC/CHL-TR-11-10. Vicksburg, MS.

Lin, Demirbilek, Mase, Zheng, and Yamada (2008): CMSWave: A nearshore spectral wave processes model for coastal inlets and navigation projects. Technical Report ERDC/CHL-TR-08-13. Vicksburg, MS.

McFall, Smith, Pollock, Rosati III, and Brutsché (2016): Evaluating sediment mobility for siting nearshore berms. Technical Note ERDC/CHETN-IV-108. Vicksburg, MS.

Thieler, Himmelstoss, Zichichi, and Ayhan (2008): Digital Shoreline Analysis System (DSAS) Version 4.0-An ArcGIS Extension for Calculating Shoreline Change. USGS Open File Report 1278. 